\title{
Training Needs and Issues Recognized by Public Health Nurses Involved in Prevention of Child Abuse
}

Hiroko Hashimoto* and Kumi Takahashi

Department of Child Health and Nursing, Institute of Biomedical Sciences, Tokushima University Graduate School, Tokushima, Japan

\section{Abstract}

Background: The number of child abuse cases continues to increase in Japan. Under these circumstances, public health nurses (PHNs) who provide continued support to children and their families play important roles in dealing with child abuse. Therefore, it is necessary to consider the support that PHNs require to perform their duties. The purpose of this study was to clarify the training needs and issues recognized by PHNs involved in prevention of child abuse.

Methods: A questionnaire survey was administered to PHNs involved in prevention of child abuse in municipalities and public health centers in Japan. Descriptions regarding training needs and issues were analyzed qualitatively.

Results: The contents of training that PHNs required were diverse. Among them, the most common training need was "ways to approach and support parents", followed by "case study" and "role and response as a PHN". Training needs differed according to the duration of experience as a PHN. The issues recognized by PHNs were "improvement of necessary system for support", "development system to support supporters", "enhancement of human resources" and "advancement of cooperation with relevant organizations".

Conclusion: The training needs of PHNs involved in prevention of child abuse varied, but there were characteristics according to the duration of experience as a PHN. It is important to reflect these needs in training contents in order to implement effective training for PHNs. The issues recognized by PHNs cannot be solved immediately through personal efforts alone; therefore, it is necessary for entire organizations to approach the issues.

\section{Introduction}

Child abuse has various influences on children's physical [1] and mental well-being [1,2]. Prevention of child abuse is an important problem that society as a whole must recognize. In order to prevent child abuse, it is essential for health professionals to accomplish their respective roles. However, this is not an easy task. Public child welfare workers surveyed in a previous study experienced high level of burnout [3]. Health professionals face various challenges in working through child abuse cases, and they require support to sufficiently perform their duties.

Previous studies reported that health professionals felt they lacked the necessary knowledge to deal with child abuse [4,5], and they wished to improve their knowledge [6]. Foster [7] also reported that health care professionals lack knowledge about community resources and that they have various training needs. One reason why health care professionals might feel their knowledge is insufficient is because a broad range of knowledge is required to deal with child abuse, such as implementing risk assessment, supporting children and families and coordinating with concerned organizations. In light of this, training for health professionals involved in prevention of child abuse should be a priority. Moreover, a study of pediatric nurse practitioners reported that continuing education on child abuse was positively related to practitioners' confidence in identifying and managing child abuse cases [8].

In Japan, public health nurses (PHNs) are continuously involved with children and their families from pregnancy onwards. PHNs therefore play an important role in preventing child abuse, early detection of suspected child abuse cases, and providing support to children and families that experience problems. It is necessary to understand the training contents that PHNs need and to provide support. original author and source are credited.

\section{Publication History:}

Received: June 01, 2020

Accepted: June 29, 2020

Published: July 01, 2020

\section{Keywords:}

Child abuse, Issues, Public health nurses, Training needs studies have reported on the training, systems and support measures required for PHNs involved in prevention of child abuse [9-11]. One study on physicians, nurses and social workers found that training needs were greater for professionals with less experience in dealing with maltreatment cases [12]. Considering the fact that the ability of PHNs to execute their professional duties increases with experience [13-15], the training needs of PHNs might differ according to the duration of their work experience. In order to design useful training contents for PHNs, it is necessary to consider the characteristics of PHNs. Although the training needs of PHNs have been reported based on their affiliated organizations [9], there is still some uncertainty regarding training needs based on the duration of experience as a PHN. Moreover, PHNs recognize the importance of not only improving their own capabilities, but also improving the system to prevent child abuse in the community [10]. Understanding what PHNs feel should be improved to deal with child abuse cases will provide background information for the development of useful

We previously administered a questionnaire survey to determine the support required by PHNs, and reported the difficulties faced by

*Corresponding Author: Dr. Hiroko Hashimoto, Department of Child Health and Nursing, Institute of Biomedical Sciences, Tokushima University Graduate School, 3-18-15 Kuramoto-cho, Tokushima City, Tokushima 770-8509, Japan, Tel/Fax: +81-88-633-9329; E-mail: hhashimoto@tokushima-u.ac.jp

Citation: Hashimoto H, Takahashi K (2020) Training Needs and Issues Recognized by Public Health Nurses Involved in Prevention of Child Abuse. Int J Nurs Clin Pract 7: 328. doi: https://doi.org/10.15344/2394-4978/2020/325

Copyright: (C) 2020 Hashimoto. This is an open-access article distributed under the terms of the Creative Commons Attribution License, which permits unrestricted use, distribution, and reproduction in any medium, provided the 
PHNs and the factors related to those difficulties [16]. This study was conducted as part of the previous questionnaire survey and aimed to clarify the training needs and issues recognized by PHNs involved in prevention of child abuse.

\section{Methods}

\section{Study participants}

The study participants were PHNs involved in prevention of child abuse working in public health centers and municipalities nationwide in Japan.

We randomly selected 110 public health centers from existing data records of the Japanese Association of Public Health Center Directors (2017) [17], and 393 municipalities from records of the Ministry of Internal Affairs and Communications (2016) [18], reaching a total of approximately one-fifth of the public health centers and municipalities nationwide. First, a request to participate in the survey was sent to the directors of each institution, and after obtaining agreement from the directors, anonymous self-administered questionnaires were distributed to the PHNs involved in prevention of child abuse at each institution. A pre-paid return envelope was provided, and completed questionnaires were returned directly to the researcher. The questionnaire was distributed to 447 PHNs affiliated with 144 facilities that agreed to cooperate in the study. The survey was conducted between November 2017 and March 2018.

\section{Survey items}

The questionnaire consisted of the following items: participant characteristics (gender, age, affiliated organization, duration of experience as a PHN, current position, population of municipality in which the respondent worked, number of PHNs in the affiliated organization, training experience in child abuse, and number of child abuse cases the respondent had been involved in to date), 50 items on degree of difficulty in dealing with child abuse cases, training contents PHNs required, and an open-ended question about involvement in prevention of child abuse. The item on training contents was asked in descriptive format. The questionnaire was revised and finalized based on the results of a pilot version administered to $10 \mathrm{PHNs}$.

\section{Analysis}

Descriptions related to training needs were extracted from both responses to training contents PHNs required and the open-ended question about involvement in prevention of child abuse. These descriptions were classified qualitatively according to the similarity of contents, and then analyzed based on duration of experience as a PHN. Descriptions of issues related to involvement in prevention of child abuse recognized by PHNs were extracted from the responses to the open-ended question and the contexts were coded. Codes were then sub-categorized and categorized according to similarities. We considered differences between coworkers in this process.

\section{Ethical considerations}

This study was conducted with the approval of the Clinical Research Ethics Review Board of Tokushima University Hospital (approval number: 2976). All participants were provided a written request to

\section{Data collection}

participate in the study, including an explanation of the purpose and method of the study, the voluntary nature of participation in the study, management of the data, and the guarantee of anonymity. Participants were assured there would be no disadvantages if they chose not to participate.

\section{Results}

A total of 337 of the 447 distributed questionnaires were returned (response rate: $75.4 \%$ ). Of these, those with complete responses to the questionnaire items, and valid responses on training contents and the open-ended question from participants with experience in child abuse cases were included in the analysis.

\section{Training needs of PHNs}

Valid responses regarding training needs were collected from 112 participants. The characteristics of the participants are shown in Table 1.

\begin{tabular}{|c|c|c|c|}
\hline & & $\mathrm{n}$ & $\%$ \\
\hline \multirow{5}{*}{$\begin{array}{l}\text { Affiliated } \\
\text { organization }\end{array}$} & Municipalities (health centers) & 61 & $54.5 \%$ \\
\hline & Municipalities (non health centers) & 28 & $25.0 \%$ \\
\hline & Public health centers & 18 & $16.1 \%$ \\
\hline & Other & 4 & $3.6 \%$ \\
\hline & Non response & 1 & $0.9 \%$ \\
\hline \multirow{4}{*}{$\begin{array}{l}\text { Experience } \\
\text { as a PHN }\end{array}$} & $1-5$ years & 23 & $20.5 \%$ \\
\hline & $6-10$ years & 26 & $23.2 \%$ \\
\hline & $\geq 21$ years & 37 & $33.0 \%$ \\
\hline & Non response & 1 & $0.9 \%$ \\
\hline \multirow[t]{4}{*}{ Position } & Staff level & 73 & $65.2 \%$ \\
\hline & Manager level or higher & 36 & $32.1 \%$ \\
\hline & Other & 2 & $1.8 \%$ \\
\hline & Non response & 1 & $0.9 \%$ \\
\hline \multirow{4}{*}{$\begin{array}{l}\text { Municipality } \\
\text { population }\end{array}$} & $<10,000$ & 25 & $22.3 \%$ \\
\hline & $10,000-50,000$ & 36 & $32.1 \%$ \\
\hline & $50,000-200,000$ & 31 & $27.7 \%$ \\
\hline & $\geq 200,000$ & 20 & $17.9 \%$ \\
\hline \multirow{4}{*}{$\begin{array}{l}\text { Number of } \\
\text { PHNs in } \\
\text { the affiliated } \\
\text { organization }\end{array}$} & $<10$ & 51 & $45.5 \%$ \\
\hline & $10-20$ & 39 & $34.8 \%$ \\
\hline & $20-30$ & 16 & $14.3 \%$ \\
\hline & $\geq 30$ & 6 & $5.4 \%$ \\
\hline \multirow{6}{*}{$\begin{array}{l}\text { Training } \\
\text { experience } \\
\text { in the child } \\
\text { abuse }\end{array}$} & Experienced & & \\
\hline & $\begin{array}{l}\text { More than once a year in the past } \\
5 \text { years }\end{array}$ & 45 & $40.2 \%$ \\
\hline & More than once in the past 5 years & 45 & $40.2 \%$ \\
\hline & No experience in past 5 years & 11 & $9.8 \%$ \\
\hline & Non-response about frequency & 2 & $1.8 \%$ \\
\hline & No training experience & 9 & $8.0 \%$ \\
\hline \multirow{4}{*}{$\begin{array}{l}\text { Number } \\
\text { of child } \\
\text { abuse cases } \\
\text { involved }\end{array}$} & $<10$ cases & 60 & $53.6 \%$ \\
\hline & $10-30$ cases & 26 & $23.2 \%$ \\
\hline & $30-50$ cases & 9 & $8.0 \%$ \\
\hline & $\geq 50$ cases & 17 & $15.2 \%$ \\
\hline
\end{tabular}


Citation: Hashimoto H, Takahashi K (2020) Training Needs and Issues Recognized by Public Health Nurses Involved in Prevention of Child Abuse. Int J Nurs Clin Pract 7: 328. doi: https://doi.org/10.15344/2394-4978/2020/325

Page 3 of 6

All respondents were women, and the mean age was 39.0 years (standard deviation \pm 9.68 ). The number of years of experience as a PHN was classified into four groups (1-5 years, 6-10 years, 11-20 years, and $\geq 21$ years). The group with $\geq 21$ years of experience was the largest with 37 nurses (33.0\%). Only nine respondents had not received training on child abuse at the time of the survey.

The results of the analysis are shown in Table 2. The contents of training that PHNs require were as follows: "ways to approach and support parents," "case study," "role and response as a PHN," "cooperation with relevant organizations," "assessment of risk factors and urgency," "ways to approach and support abused children," "necessary knowledge regarding support for child abuse cases," "related laws and social systems," "ways to approach and support families," "influence of abuse on children," "preventive measures for child abuse," "support for the supporters," and "others".

Among the contents, the most common response was "ways to approach and support parents" (approximately one-third of the respondents analyzed), followed by "case study" and "role and response as a PHN." "Ways to approach and support parents" included ways to approach and support parents who abused their children, refused support, did not admit abuse, and who had mental illness, developmental disorder and a history of abuse."Case study" included analysis of child abuse cases and descriptions of both cases that went well and those that were difficult. "Role and response as a PHN" included initial response as a PHN when they received notice of child abuse and the role of supporting maternal and child health. "Necessary knowledge regarding support for child abuse cases" included financial issues and attachment building between the parent and their child.

\section{Training needs according to the duration of experience as a PHN}

One participant did not provide a response to the question about the duration of experience as a PHN. The duration of experience for the remaining 111 respondents was1-5 years $(n=23), 6-10$ years $(n=26), 11-20$ years $(n=25)$ and $\geq 21$ years $(n=37)$. The training needs of each group are shown in Table 3 . The results showed that "ways to approach and support parents" was the most frequent response in all groups, but the second most frequent response differed between groups. "Case study," "role and response as a PHN" and "cooperation with relevant organizations" were more frequent among respondents with 1-5 years and 6-10 years of experience. Among respondents with 11-20 years of experience, "assessment of risk factors and urgency" and "ways to approach and support abused children" were more frequent than "role and response as a PHN" and "cooperation with relevant organizations". Among those with $\geq 21$ years of experience, responses of "co-operation with relevant organizations" and "related laws and social systems" were more frequent than "case study".

\begin{tabular}{|c|c|}
\hline Contents & Main descriptions \\
\hline \multirow[t]{2}{*}{$\begin{array}{l}\text { Ways to approach and support } \\
\text { parents }\end{array}$} & $\begin{array}{l}\text { Way to approach parents who abused their children, refused supports, and did not admit that they abused } \\
\text { their children }\end{array}$ \\
\hline & Ways to approach and support parents with mental illness, developmental disorder, history of abused \\
\hline \multirow[t]{2}{*}{ Case study } & Analysis of cases \\
\hline & Introduction to successful and difficult cases \\
\hline \multirow[t]{2}{*}{ Role and response as a PHN } & Initial response as a PHN when they received notice of the abuse \\
\hline & Role in maternal and child health to prevent child abuse \\
\hline \multirow[t]{2}{*}{$\begin{array}{l}\text { Cooperation with relevant } \\
\text { organizations }\end{array}$} & $\begin{array}{l}\text { Ways to cooperate with relevant organizations including child consultation centers, elementary and junior } \\
\text { high school, and municipalities }\end{array}$ \\
\hline & Way to exchange information with relevant organizations \\
\hline \multirow{2}{*}{$\begin{array}{l}\text { Assessment of risk factor and } \\
\text { urgency }\end{array}$} & Ways to determine the risk of child abuse \\
\hline & Ways to determine the urgency of support for the case \\
\hline \multirow{2}{*}{$\begin{array}{l}\text { Ways to approach and support } \\
\text { abused children }\end{array}$} & Ways to approach abused children \\
\hline & Ways to support abused children \\
\hline \multirow{2}{*}{$\begin{array}{l}\text { Necessary knowledge regarding } \\
\text { support for child abuse cases }\end{array}$} & Relation between child abuse and economic issue \\
\hline & Attachment building between parent and their child \\
\hline \multirow[t]{2}{*}{ Related laws and social systems } & Foster parent system \\
\hline & Special adoption \\
\hline \multirow{2}{*}{$\begin{array}{l}\text { Ways to approach and support } \\
\text { families }\end{array}$} & Ways to support families facing many problems \\
\hline & Ways to approach families suspected child abuse \\
\hline \multirow[t]{2}{*}{ Influence of abuse on children } & Influence of abuse on children's brain and development \\
\hline & Psychology of abused children \\
\hline Preventive measures for child abuse & Preventive measures for child abuse with evidence \\
\hline \multirow[t]{2}{*}{ Support for the supporter } & Support for the supporters \\
\hline & Mental care of the supporters \\
\hline \multirow[t]{2}{*}{ Others } & Management of regional council of countermeasures for child requiring protection \\
\hline & Staff placement \\
\hline
\end{tabular}

Table 2: Training needs of PHNs involved in prevention of child abuse. 
Citation: Hashimoto H, Takahashi K (2020) Training Needs and Issues Recognized by Public Health Nurses Involved in Prevention of Child Abuse. Int J Nurs Clin Pract 7: 328. doi: https://doi.org/10.15344/2394-4978/2020/325

Page 4 of 6

Regarding the "role and response as a PHN", responses of "the role as a PHN" and "initial response as a PHN when they received notice of the abuse" were frequent among respondents with 1-5 years and 6-10 years of experience. However, among those with $\geq 21$ years of experience, responses focusing on the specialization of PHNs, such as "working to prevent child abuse by providing maternal and child health care" and "how to grasp the tasks of PHNs and the child welfare system," were more frequent.

\section{Issues recognized by PHNs}

Ninety PHNs provided responses to the open-ended question about involvement in child abuse cases, and among them, descriptions regarding issues were extracted from 37 PHNs. All 37 respondents were women, and the mean age was 41.4 years (standard deviation, \pm 8.71). One respondent did not provide a response for their duration of experience as a PHN. The duration of experience for the remaining 36 respondents was as follows: $1-5$ years $(n=6), 6-10$ years $(n=6), 11-20$ years $(n=11)$, and $\geq 21$ years $(n=13)$. Approximately one-third of the respondents had $\geq 21$ years of experience as a PHN. Four $<$ categories $>$ and nine [subcategories] were extracted as issues recognized by PHNs involved in prevention of child abuse. The categories comprised <improvement of necessary system for support>, <development system to support supporters $>$, <enhancement of human resources $>$, and <advancement of cooperation with relevant organizations $>$.

$<$ Improvement of necessary system for support> consisted of three subcategories: [efforts of the entire organization] such as making a conscious effort towards co-operation among departments in the entire organization; [system to provide continuous support] which involved supporting children and their families without a break; and [approach by the prefectural government], since there are limits to the approaches taken by individual municipalities.

$<$ Development system to support supporters $>$ consisted of two subcategories: PHNs needed [the opportunity to obtain supervision] in supporting child abuse cases; and [support for supporters] in order to lighten the psychological burden of supporters.

$<$ Enhancement of human resources $>$ consisted of two subcategories: PHNs felt there was a lack of manpower in supporting child abuse cases, and needed an [increase of staff]. Furthermore, PHNs required an [increase in the placement of professionals] at child consultation centers and in municipalities.

<Advancement of cooperation with relevant organizations> consisted of two subcategories: PHNs recognized the need for [cooperation with relevant organizations], and considered how to build a system of [sharing information with relevant organizations].

\section{Discussion}

The results of this study showed that the training needs of PHNs involved in prevention of child abuse were diverse. These needs included not only ways to approach and support parents, children and families but also case study, roles and responses as a PHN

\begin{tabular}{|c|c|c|c|c|c|c|c|}
\hline \multicolumn{2}{|c|}{$1-5$ years $n=23$} & \multicolumn{2}{|c|}{$6-10$ years $n=26$} & \multicolumn{2}{|c|}{$11-20$ years $n=25$} & \multicolumn{2}{|c|}{$\geq 21$ years $n=37$} \\
\hline Contents & $\mathrm{n}(\%)$ & Contents & $\mathrm{n}(\%)$ & Contents & $\mathrm{n}(\%)$ & Contents & $\mathrm{n}(\%)$ \\
\hline $\begin{array}{l}\text { Ways to approach } \\
\text { and support parents }\end{array}$ & $7(30.4 \%)$ & $\begin{array}{l}\text { Ways to approach } \\
\text { and support parents }\end{array}$ & $8(30.8 \%)$ & $\begin{array}{l}\text { Ways to approach and } \\
\text { support parents }\end{array}$ & $10(40.0 \%)$ & $\begin{array}{l}\text { Ways to approach and } \\
\text { support parents }\end{array}$ & $11(29.7 \%)$ \\
\hline $\begin{array}{l}\text { Role and response as } \\
\text { a } \mathrm{PHN}\end{array}$ & $5(21.7 \%)$ & Case study & $8(30.8 \%)$ & Case study & $5(20.0 \%)$ & $\begin{array}{l}\text { Cooperations with } \\
\text { relevant organization }\end{array}$ & $7(18.9 \%)$ \\
\hline Case study & $4(17.4 \%)$ & $\begin{array}{l}\text { Role and response as } \\
\text { a PHN }\end{array}$ & $7(26.9 \%)$ & $\begin{array}{l}\text { Assessment of risk } \\
\text { factor and urgency }\end{array}$ & $4(16.0 \%)$ & $\begin{array}{l}\text { Role and response as } \\
\text { a PHN }\end{array}$ & $6(16.2 \%)$ \\
\hline $\begin{array}{l}\text { Cooperation with } \\
\text { relevant organization }\end{array}$ & $4(17.4 \%)$ & $\begin{array}{l}\text { Cooperation with } \\
\text { relevant organization }\end{array}$ & $4(15.4 \%)$ & $\begin{array}{l}\text { Ways to approach } \\
\text { and support abused } \\
\text { children }\end{array}$ & $4(16.0 \%)$ & $\begin{array}{l}\text { Related laws and } \\
\text { social system }\end{array}$ & $6(16.2 \%)$ \\
\hline $\begin{array}{l}\text { Assessment of risk } \\
\text { factor and urgency }\end{array}$ & $3(13.0 \%)$ & $\begin{array}{l}\text { Influence of abuse on } \\
\text { children }\end{array}$ & $4(15.4 \%)$ & $\begin{array}{l}\text { Cooperation with } \\
\text { relevant organization }\end{array}$ & $2(8.0 \%)$ & Case study & $4(10.8 \%)$ \\
\hline $\begin{array}{l}\text { Ways to approach } \\
\text { and support families }\end{array}$ & $3(13.0 \%)$ & $\begin{array}{l}\text { Necessary knowledge } \\
\text { regarding support for } \\
\text { child abuse cases }\end{array}$ & $3(11.5 \%)$ & $\begin{array}{l}\text { Necessary knowledge } \\
\text { regarding support for } \\
\text { child abuse cases }\end{array}$ & $2(8.0 \%)$ & $\begin{array}{l}\text { Necessary knowledge } \\
\text { regarding support for } \\
\text { child abuse cases }\end{array}$ & $4(10.8 \%)$ \\
\hline $\begin{array}{l}\text { Ways to approach } \\
\text { and support abused } \\
\text { children }\end{array}$ & $2(8.7 \%)$ & $\begin{array}{l}\text { Assessment of risk } \\
\text { factor and urgency }\end{array}$ & $2(7.7 \%)$ & $\begin{array}{l}\text { Ways to approach and } \\
\text { support families }\end{array}$ & $2(8.0 \%)$ & $\begin{array}{l}\text { Assessment of risk } \\
\text { factor and urgency }\end{array}$ & $2(5.4 \%)$ \\
\hline $\begin{array}{l}\text { Necessary knowledge } \\
\text { regarding support for } \\
\text { child abuse cases }\end{array}$ & $2(8.7 \%)$ & $\begin{array}{l}\text { Ways to approach } \\
\text { and support abused } \\
\text { children }\end{array}$ & $2(7.7 \%)$ & $\begin{array}{l}\text { Role and response as } \\
\text { a PHN }\end{array}$ & $1(4.0 \%)$ & $\begin{array}{l}\text { Ways to approach } \\
\text { and support abused } \\
\text { children }\end{array}$ & $2(5.4 \%)$ \\
\hline $\begin{array}{l}\text { Influence of abuse on } \\
\text { children }\end{array}$ & $1(4.3 \%)$ & $\begin{array}{l}\text { Related laws and } \\
\text { social systems }\end{array}$ & $2(7.7 \%)$ & $\begin{array}{l}\text { Related laws and } \\
\text { social systems }\end{array}$ & $1(4.0 \%)$ & $\begin{array}{l}\text { Ways to approach and } \\
\text { support families }\end{array}$ & $2(5.4 \%)$ \\
\hline $\begin{array}{l}\text { Support for the } \\
\text { supporter }\end{array}$ & $1(4.3 \%)$ & $\begin{array}{l}\text { Ways to approach } \\
\text { and support families }\end{array}$ & $1(3.8 \%)$ & $\begin{array}{l}\text { Influence of abuse on } \\
\text { children }\end{array}$ & $1(4.0 \%)$ & $\begin{array}{l}\text { Influence of abuse on } \\
\text { children }\end{array}$ & $1(2.7 \%)$ \\
\hline $\begin{array}{l}\text { Related laws and } \\
\text { social systems }\end{array}$ & 0 & $\begin{array}{l}\text { Preventive measures } \\
\text { for child abuse }\end{array}$ & 0 & $\begin{array}{l}\text { Preventive measures } \\
\text { for child abuse }\end{array}$ & $1(4.0 \%)$ & $\begin{array}{l}\text { Preventive measures } \\
\text { for child abuse }\end{array}$ & $1(2.7 \%)$ \\
\hline $\begin{array}{l}\text { Preventive measures } \\
\text { for child abuse }\end{array}$ & 0 & $\begin{array}{l}\text { Support for the } \\
\text { supporter }\end{array}$ & 0 & $\begin{array}{l}\text { Support for the } \\
\text { supporter }\end{array}$ & 0 & $\begin{array}{l}\text { Support for the } \\
\text { supporter }\end{array}$ & $1(2.7 \%)$ \\
\hline
\end{tabular}

Table 3: Training needs according to the years of experience as a PHN 
and cooperation with relevant organizations. Above all, the most frequently mentioned need was ways to approach and support parents. In a previous study that investigated the training needs of PHNs, needs to support individual cases were strongest, followed by needs to support families among PHNs with experience in providing support for child abuse cases [9]. Establishing a relationship of trust with parents is very important for PHNs in dealing with child abuse cases. However, this is very difficult with parents who have various problems and refuse support. Therefore, how to approach parents and provide support is considered an urgent problem for PHNs, and the need for training on this topic is high.

Case study was mentioned frequently, followed by ways to approach and support parents. Previous study reported that PHNs' view on families and the contents of support by PHNs have been found to change through case study [19]. In light of this, case study might be part of necessary training for PHNs' practice. In the present study, many PHNs indicated that they wanted to learn about both difficult cases and successful cases. PHNs may be trying to gain useful information to wrestle with the problems they face in daily practice by learning through various case studies. In addition, for PHNs involved with child abuse cases, various processes are required, such assessing the need for support, providing support to children and families and cooperating with relevant organizations. Therefore, the need for training with case studies is high for PHNs since it is useful in helping them understand the overall progress of the support provided.

Although the training contents that PHNs required varied, there were characteristics based on the duration of experience as a PHN. Case study was indicated as important among PHNs with 1-5 years, 6-10 years and 11-20 years of experience, but "cooperation with relevant organizations" and "related laws and social systems" were indicated as more important than case study among those with $\geq 21$ years of experience. The reason why case study had a lower priority among PHNs with $\geq 21$ years of experience was thought to be because they have dealt with various cases through their careers, and these actual experiences replaced the need for case study. PHNs with $\geq 21$ years of experience indicated that "related laws and social systems" was the third most need for training. Understanding the laws and social systems related to child abuse is essential, but these laws and systems are often amended according to the present state of society, and it is necessary for PHNs to consider how such revisions influence their practice. PHNs with $\geq 21$ years of experience are in a position to advise other PHNs and play an important role in disseminating information about legal and systemic changes; therefore, they ranked related laws and social systems as a high-priority training need.

In this study, four categories (<improvement of necessary system for support>, <development system to support supporters>, $<$ enhancement of human resources $>$, <advancement of cooperation with relevant organizations $>$ ) were extracted as issues recognized by PHNs involved in prevention of child abuse. When PHNs provide support on child abuse cases, co-operation with both relevant departments and organizations is essential. However, as shown by the results of this study, such systems may not necessarily be sufficient. Previous study also reported that the importance and difficulty of establishing support systems to prevent child abuse has been recognized by health professionals [20]. The development of these systems cannot be realized immediately by personal effort alone; therefore, it is necessary for entire organizations to approach the issues. Concerning <development system to support supporters>, since detecting and reporting child maltreatment is stressful for child health care nurses [21], PHNs involved in prevention of child abuse may also have various anxiety and conflict. It is essential to reduce the psychological burden on PHNs. The need for supervision has been reported in previous studies [11,21]. The present study also showed that the opportunity for supervision was recognized as an issue by PHNs, that is, it seems hard for PHNs to obtain meaningful supervision in the current situation. It is necessary to examine appropriate supervision that is easy to utilize for PHNs. The number of child abuse cases increases year by year in Japan [22], and the roles demanded of PHNs widen. However, an increase in the number of PHNs is not enough to meet the increased responsibilities of their role. Under these conditions, it may be said that <enhancement of human resources $>$ is an earnest need of PHNs. PHNs hope that the enhancement of human resources not only increases the manpower, but also increases the placement of specialists at each related organization involved in prevention of child abuse. Professionals from multiple disciplines involved in child abuse cases and PHNs recognize the importance of cooperation with relevant organizations. Therefore, it is thought that PHNs also expressed the need for the appropriate placement of other professionals related to child abuse cases.

\section{Limitations}

This study analyzed the training needs and issues recognized by PHNs through a questionnaire survey. However, less than half of the PHNs who responded to the questionnaire in this study provided responses related to training needs and issues. Therefore, it is difficult to understand the opinion of all participants. Further study is required to investigate the training needs of PHNs in a qualitative and quantitative manner.

\section{Conclusions}

This study administered a questionnaire survey to clarify the features of training needs and the issues recognized by PHNs involved in prevention of child abuse. There were some similarities in training needs based on the duration of experience as a PHN. PHNs recognized issues such as the system, human resources and co-operation. It is essential to reflect on these needs and issues to provide the necessary support for PHNs.

\section{Author Contributions}

H. H. and K. T. contributed to the conception and design of this study, and carried out data analysis. H. H. conducted data collection and drafted the manuscript. H. H. and K. T. read and approved the final manuscript.

\section{Acknowledgements}

The authors would like to thank the PHNs who participated in this study. This work was supported by JSPS KAKENHI Grant Number JP16K12296.

\section{Competing Interests}

The authors declare that there is no competing interests regarding the publication of this article.

\section{References}

1. Springer KW, Sheridan J, Kuo D, Carnes M (2007) Long-term physical and mental health consequences of childhood physical abuse: results from a large population-based sample of men and women. Child Abuse Negl 31: 517-530. 
2. Fergusson DM, Boden JM, Horwood L (2008) Exposure to childhood sexual and physical abuse and adjustment in early adulthood. Child Abuse Negl 32: 607-619.

3. Boyas J, Wind LH (2010) Employment-based social capital, job stress, and employee burnout: A public child welfare employee structural model. Children and Youth Services Review 32: 380-388.

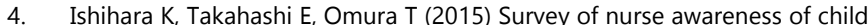
abuse and appropriate countermeasures. Journal of Japanese Soeiety of Child Health Nursing 24: 10-17.

5. Li X, Yue Q, Wang S, Wang H, Jiang J, et al. (2017) Knowledge, attitudes, and behaviours of healthcare professionals regarding child maltreatment in China. Child Care Health Dev 43: 869-875.

6. Sathiadas MG, Viswalingam A, Vijayaratnam K (2018) Child abuse and neglect in the Jaffna district of Sri Lanka - a study on knowledge attitude practices and behavior of health care professionals. BMC Pediatr 18: 152.

7. Foster RH, Olson-Dorff D, Reiland HM, Budzak-Garza A (2017) Commitment confidence, and concerns: Assessing health care professionals' child maltreatment reporting attitudes. Child Abuse Negl 67: 54-63.

8. Herendeen PA, Blevins R, Anson E, Smith J (2014) Barriers to and consequences of mandated reporting of child abuse by nurse practitioners. J Pediatr Health Care 28: 1-7.

9. Nakaita I, Makino S, Tousaka M, Takahashi Y, Watanabe Y, et al. (2005) Public health nurse self-evaluation and issues in activities for prevention of child abuse. Japanese Society for Prevention of Child Abuse and Neglect 7: 24-30.

10. Abe A, Iimura T, Nagai M, Yoshino J, Morita M, et al. (2008) A study about the confidence and the formulation of capability to be effective in child abuse prevention of the public health nurses: the study was conducted on public health nurses belonging to the public health centers in $\mathrm{H}$ prefecture. Bulletin of the Japanese Red Cross Hiroshima College of Nursing 8: 39-48.

11. Yamashiro S, Maeda K, Ueda R, Numaguchi C, Morishima S, et al. (2008) Educational needs of professionals in child abuse prevention: one of Okinawa Islands in Japan. Journal of Okinawa Prefectural College of Nursing 9: 1-9.

12. Yehuda YB, Attar-Schwartz S, Ziv A, Jedwab M, Benbenishty R, et al. (2010) Child abuse and neglect: reporting by health professionals and their need for training. Isr Med Assoc J 12: 598-602.

13. Guo SJ, Hsu CH, Lin CJ (2008) A study of community healthcare competency among public health nurses. J Nurs Res 16: 286-296.

14. Iwamoto S, Okamoto R, Shiomi M (2008) Development and evaluation of the reliability and validity of a scale for basic actions relevant to public health. Nihon Koshu Eisei Zasshi 55: 629-639.

15. Saeki K, Izumi H, Uza M, Murashima S (2007) Factors associated with the professional competencies of public health nurses employed by local government agencies in Japan. Public Health Nursing 24: 449-457.

16. Hashimoto H, Takahashi K (2020) Difficulties faced by public health nurses involved in prevention of child abuse. The Journal of Nursing Investigation.

17. Japanese Association of Public Health Center Directors (2017) Public Health Center list.

18. Ministry of Internal Affairs and Communications (2016) Prefectural code and municipal code.

19. Kobayashi K (2011) Changes in Awareness and Care Practices on the part of Public Health Nurses through Participation in an Action Research-based Case Study Group on Child Abuse and Neglect. Journal of Japan Society of Nursing Research 34: 131-142.

20. Nodaka T, Fujimaru T, Yamamoto H, Kajihara K, Hirata N, et al. (2016) A Discussion of a Child Abuse Prevention Training Program for Midwives Working in Medical Facilitie - A trial of making program based on a questionnaire survey of health professionals working in administrative bodies. Bulletin of Faculty of Medical Technology, Teikyo University, Fukuoka 11: 21-31.

21. Dahlbo M, Jakobsson L, Lundqvist $P$ (2017) Keeping the child in focus while supporting the family: Swedish child healthcare nurses experiences of encountering families where child maltreatment is present or suspected. $J$ Child Health Care 21: 103-111.

22. Ministry of Health, Labour and Welfare (2019) Number of Child Abuse Consultation at Child Guidance Center in Fiscal Year 2018.

This article was originally published in a special issue:

Community-Based Participatory Research Practices-Vol II

Handled by Editor(s):

Prof. Reiko Okahisa

Department of Community Health Nursing

Tokushima University

Japan 